\title{
Retrospective analysis of prognostic factors affecting the recurrence and disease-free survival following surgical management of gastrointestinal stromal tumors
}

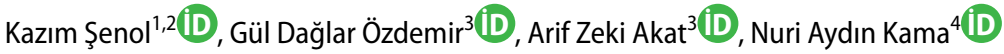 \\ ${ }^{1}$ Department of General Surgery, Uludag University School of Medicine, Bursa, Turkey \\ ${ }^{2}$ Department of General Surgery, Ankara Numune Training and Research Hospital, Ankara, Turkey \\ ${ }^{3}$ Department of General Surgery, Health Sciences University School of Medicine, Ankara, Turkey \\ ${ }^{4}$ Department of General Surgery, Abant Izzet Baysal University School of Medicine, Bolu, Turkey
}

\begin{abstract}
Objective: The aim of this study was to evaluate the prognostic factors effecting recurrence risk and disease-free survival of the patients who were diagnosed as gastrointestinal stromal tumor after complete resection of the tumor with or without adjuvant therapy.

Material and Methods: Between the years 2005 and 2013, data of 71 patients including clinical and demographic features, tumor localizations, pathologic examinations, survival and recurrence rates were enrolled into this retrospective study.

Results: Male/female ratio was 1.71, and mean age was $60.27 \pm 14.65$ years. Forty-two (59.2\%) patients had tumor in stomach, 16 (22.5\%) in small bowel, whereas $12(16.9 \%)$ had extra-gastrointestinal system and one patient (\%1.4) had rectal localization. Modified NIH risk stratification scheme categorized 9 (12.68\%) patients in very low-, 12 (16.90\%) in low-, 21 (29.58\%) patients in moderate-and 29 (40.85\%) patients in high-risk group. Twenty-four (33.8\%) patients had a metastatic disease at follow-up while $13(18.3 \%)$ patients were metastatic at admission. R0 resection was successfully performed in 51 (71.8\%) patients, while R1 resection in 9 (12.7\%) and R2 resection in 11 (15.5\%) were achieved. Mean follow-up time was $47.12 \pm 33.52$ months (range, 1-171 months). Nineteen (26.8\%) patients demonstrated recurrence with a mean time of $22.16 \pm 15.89$ months (range, 3-57 months). During follow-up 17 (23.9\%) patients were deceased. In univariate analysis, high-risk group, small bowel and extra-gastrointestinal system localization, R1-2 resection, necrosis, positive resection margin and invasion of surrounding tissues, metastatic disease and adjuvant therapy were statistically significant in terms of recurrence. Multivariate analysis presented small bowel and extra-gastrointestinal system localization, R2 resection, mitoses count, invasion and adjuvant therapy as independent prognostic risk factors affecting disease-free survival rates. The 1,3 and 5 years of disease-free survival rates of the patients were $89.6 \%, 75.4 \%$, $64.3 \%$, respectively.

Conclusion: As mentioned in the literature, the mainstay of curative therapy of gastrointestinal stromal tumor is surgery. In our study, not only small bowel, extra-gastrointestinal system localization and invasion of surrounding tissues by tumor, but also R2 resection that complicate the local control of the disease were represented as independent adverse prognostic factors for disease-free survival. Unfavourable clinical outcomes of adjuvant therapy over the disease-free survival was linked to higher tumor stage with metastatic disease and emphasized that prospective trials with more cases should be practiced.
\end{abstract}

Keywords: Gastrointestinal stromal tumors, surgery, prognosis, disease specific survival

Cite this article as: Şenol K, Dağlar Özdemir G, Akat AZ, Kama NA. Retrospective analysis of prognostic factors affecting the recurrence and disease-free survival following surgical management of gastrointestinal stromal tumors. Turk J Surg 2020; 36 (2): 209-217.

\section{Corresponding Author}

Kazım Şenol

E-mail: kazimsenol@hotmail.com

Received: 08.11 .2018

Accepted: 29.01 .2020

Available Online Date: 08.06 .2020

○ Copyright 2020 by Turkish Surgical Society Available online at www.turkjsurg.com

DOI: $10.5578 /$ turkjsurg.4389

\section{INTRODUCTION}

Our knowledge on gastrointestinal stromal tumors (GIST) has increased exponentially as an indicator of progress in medicine, with ground-breaking advances in the diagnosis and treatment of this disease. These tumors were described as leiomyomas, leiomyosarcomas, or leiomyoblastomas in the past. GISTs are now described and accepted as the most common sarcoma of the gastrointestinal (Gl) tract as a separate entity. GISTs constitute 1-2\% of all GI malignancies and have a clinical course ranging from benign to malignant (1). It can occur anywhere in the gastrointestinal tract, and $60 \%$ is in the stomach, 30\% in the small intestine, $7 \%$ in the large intestine, $5 \%$ in the rectum, and $1 \%$ in the esophagus (2). It accounts for $2 \%$ of gastric tumors and $14 \%$ of small bowel tumors, but rarely, primary GISTs of the omentum, mesentery, and pancreas have also been described (3). At least fifty percent of the patients are metastatic on diagnosis, where the liver and peritoneum are the most two common sites of extended disease. GISTs are generally rare tumors between 3000 and 5000 new cases each year, with an annual incidence of 1/14.5 million and 
a prevalence of 1/129 million cases (4,5). Median age is 60 years, and it is observed in males with a slight difference.

In a population-based cohort study from 10 series in the literature, Joensuu et al. have demonstrated disease-free survival (DFS) rates of 1625 patients diagnosed with operable GIST, who were not given adjuvant therapy, within $5^{\text {th }}, 10^{\text {th }}, 15^{\text {th }}$ and $20^{\text {th }}$ years as $70.5 \%, 62.9 \%, 59.9 \%$ and $57.3 \%$, respectively (6). Although GIST recurrence is rare during the first 10-year follow-up, most patients recover with surgical treatment alone. Despite previous data, modern imaging modalities facilitate early diagnosis and detection of small metastatic foci. Thus, the patients who are eligible for surgery can be treated by surgery alone without adjuvant treatment for almost $60 \%$ of the cases. Surgical outcomes and DFS rates should be increased by providing early diagnosis and independent prognostic risk factors associated with disease recurrence. In this retrospective cohort study, it was aimed to evaluate and investigate the effects of clinical characteristics, adjuvant therapy and complete removal of the tumor with intact surgical margin over DFS rates in patients with GIST.

\section{MATERIAL and METHODS}

\section{Patient Selection}

The clinical, pathological, and surgical parameters and follow-up records of 71 patients with gastrointestinal stromal tumors who were admitted to the General Surgery Department between January 2005 and December 2013 were reviewed retrospectively. The study was planned in accordance with the decisions of the Declaration of Helsinki, patient rights regulation, and ethical rules. Approval was obtained from the Ankara Numune Training and Research Hospital Scientific Research Evaluation Commission for the study (Date: 29.01.2014, Decision no: 2014-748).

Age, sex, concomitant co-morbid diseases, admission symptoms, operation sort and time, length of hospital stay, tumor location, presence of perforation, tumor morphology, and immunohistochemical interpretations, adjuvant therapy, metastasis and recurrence rates were analyzed to determine the prognostic factors in patient survival.

\section{Patient Groups}

Patients were grouped according to age and decades. Tumors were located in the stomach, small intestines, large intestines, and omentum-mesentery. Tumor diameter was determined as $\leq$ $5 \mathrm{~cm},>5 \leq 10 \mathrm{~cm}$ and $>10 \mathrm{~cm}$. Mitosis rate was the number of mitosis count on a light microscope within an area of $0.152 \mathrm{~mm} 2$ at 50 high-power fields (HPF) magnification sites; and divided into three groups $\leq 5,5-10$ and $>10$. Tumor histology was interpreted as spindle, epithelioid, and mixt types. Tumor necrosis (present/absent), cellularity (poor/distinct), pleomorphism (poor/ distinct), mucosal ulceration (present/absent), in-tumor bleeding (present/absent), and tumor invasion depths were noted. Patients were divided into two groups according to adjuvant therapy history with-or without tyrosine kinase inhibitor.

\section{Follow-up}

Patients were followed up with routine whole blood and biochemical tests and abdominal ultrasound/or tomography when necessary within 3-6 month intervals for five years. Recurrenceor metastasis-free patients were followed up annually. Patients with additional complaints during follow-up were evaluated by gastroscopy, colonoscopy and further investigations. Patients with tumor recurrence or metastasis were considered for definitive surgery. Adjuvant therapy with tyrosine kinase inhibitors was maintained for high-risk patients according to the modified $\mathrm{NIH}$ consensus criteria. Adjuvant Imatinib treatment was schemed as single dose initially and doubled in progressive disease. Imatinib therapy was maintained for 1 to 3 years under the supervision of the Oncology department. Sunitinib therapy was initiated in imatinib-resistant, progressive disease. Patients were contacted via consultation or telephone within six-month intervals, and follow-up parameters of surviving patients were recorded.

\section{Statistical Analysis}

In the literature, prognostic factors were divided into valid groups for the evaluation of survival of stromal tumors, whether there was a significant difference between the groups. DFS was defined as the time from the date of diagnosis until first recurrence. Descriptive statistics are given as mean \pm standard deviation. Pearson chi-squared test was performed for comparison of homogeneity between the groups. DFS analysis and survival tables were obtained with the Kaplan-Meier method. Comparison of survival curves was tested with Log-rank test. Prognostic factors with $p$ values $<0.20$ in the Log-rank test were entered to the multivariate analysis. Multivariate analysis was performed with Cox-regression test regression. Risk ratios (Hazard ratio) in multivariate analysis within a 95\% confidence interval with a p value $<0.05$ were noted statistically significant. Statistical analysis was performed using the 'SPSS for Windows' package program.

\section{RESULTS}

Forty-eight (67.6\%) of the patients were males, with a male/ female ratio of 2.08 (48/23). Mean age was $60.27 \pm 14.65$ years (range: 22-88 years). Admission symptoms including abdominal pain, weight loss, nausea-vomiting, melena, and palpable mass regarding to stromal tumor were evaluated; 12 (16.9\%) patients were symptom-free, 15 (21.1\%) patients presented at least one, 17 (23.9\%) patients presented at least two, 15 (21.1\%) patients presented at least three, $10(14.1 \%)$ patients presented at least four, and 2 (2.8\%) patients presented all of the complaints. Although the most common complaints were abdominal pain in 50 (14\%) patients, abdominal mass in 29 (8\%) patients, nausea-vomiting in 33 (9\%) patients, most frequent symptoms in the literature regarding Gl bleeding were presented only in 12 (3\%) patients. In our study, only 15 patients described a single symptom, but several symptoms interlinked to each other due to the complicated clinical course of the disease. There was a sig- 
nificant relationship between survival and abdominal pain and mass $(p<0.05)$. A statistically significant relationship was also observed between recurrence and nausea-vomiting ( $p<0.05)$.

Tumors were located in the stomach in 42 (59.2\%) patients, small intestines in 16 (22.5\%) patients, omentum-mesentery (extra-GIS) in $12(16.9 \%)$ patients and rectum in 1 (1.4\%) patient. There were no colonic or esophageal tumors. One case with extra-GIS location was located at the pancreas. Mean tumor diameter was $7.78 \pm 5.53 \mathrm{~cm}$ (range $0.4-30 \mathrm{~cm}$ ). Tumor diameter was $<5 \mathrm{~cm}$ in 23 patients, $5-10 \mathrm{~cm}$ in 29 patients, and $>10 \mathrm{~cm}$ in 19 patients. Forty-two of the cases were spindle cells, 6 were epithelioid cells, and 16 were mixed tumors. According to Modified NIH risk scoring system based on clinical and morphological findings, nine patients were in the very low-risk group, 12 patients were in the low-risk group, 21 patients were in the intermediate-risk group, and 29 patients were in the high-risk group (Figure 1).

A total of 13 (18.3\%) patients were metastatic on admission including peritoneal dissemination in 5 (38.4\%) patients, metastatic nodules in the liver in 6 (46.1\%) patients and in lungs in 1 (7.6\%) patient and invasion to the stomach in 1 (7.6\%) extra-GIS localized patient. Postoperative metastasis was present in 9 (12.67\%) patients, including the liver in 3 (33.3\%) patients, peritoneal surfaces in 5 (55.5\%) patients, and subcutaneous tissue in $1(12.67 \%)$ patient.

A total of 71 patients were included into the study, and 17 (23.94\%) patients died during the follow-up period. Mean follow-up period was $47.12 \pm 33.52$ months, and the last event was at 1 the $71^{\text {st }}$ month. Overall survival rates of $1^{\text {st }}, 3^{\text {rd }}$, and $5^{\text {th }}$ years were $91.4 \%, 82.6 \%, 76.5 \%$, respectively. Recurrence was observed in 19 (26.8\%) patients, and mean recurrence time was $22.16 \pm 15.89$ (3-57) months. DFS rates of $1^{\text {st }}, 3^{\text {rd }}$, and $5^{\text {th }}$ years were $89.6 \%, 75.4 \%$ and $64.3 \%$, respectively (Figure 2). Recurrences were in the stomach in 7 (36.84\%) patients, small intestine

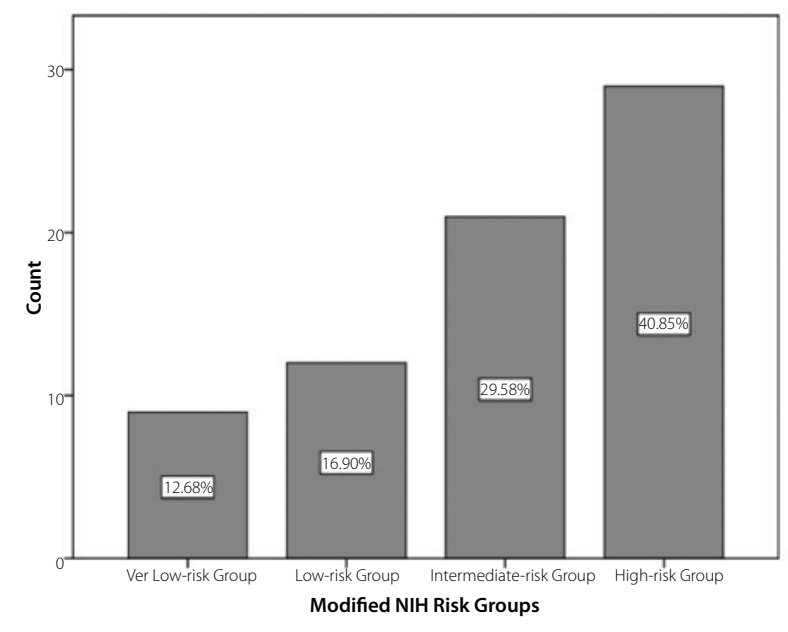

Figure 1. Distribution of the patients according to the modified NIH staging system. in 5 (26.31\%) patients and extra-GIS in 7 (36.84\%) patients. The last recurrence was observed in the $57^{\text {th }}$ month, and the patient died at the $69^{\text {th }}$ month. Twelve (70.58\%) of the 17 patients died due to stromal tumor progression and recurrences. Rectum localized GIST was recurrence-free during follow-up. Although gastric localized GISTs presented with more recurrence and recurrence-related death rates, extra-GIS localized tumors presented with lower DFS rates $(p<0.001)$ (Figure 3$)$.

Eighteen (25.4\%) patients presented with the local invasive disease during the operation. $\mathrm{R} 0$ resection was achieved in 51 (71.8\%) patients, R1 resection in 9 (12.7\%) patients and R2 resection in 11 (15.5\%) patients. Ten (14.2\%) of these patients relapsed, and 5 (7.1\%) recurrence-related deaths were observed. Only 2 (2.81\%) of the 4 (5.63\%) patients, who underwent $\mathrm{R} 0$ resection with peri-operative local invasive disease, had positive pathological surgical margins. Eight (11.3\%) patients presented with
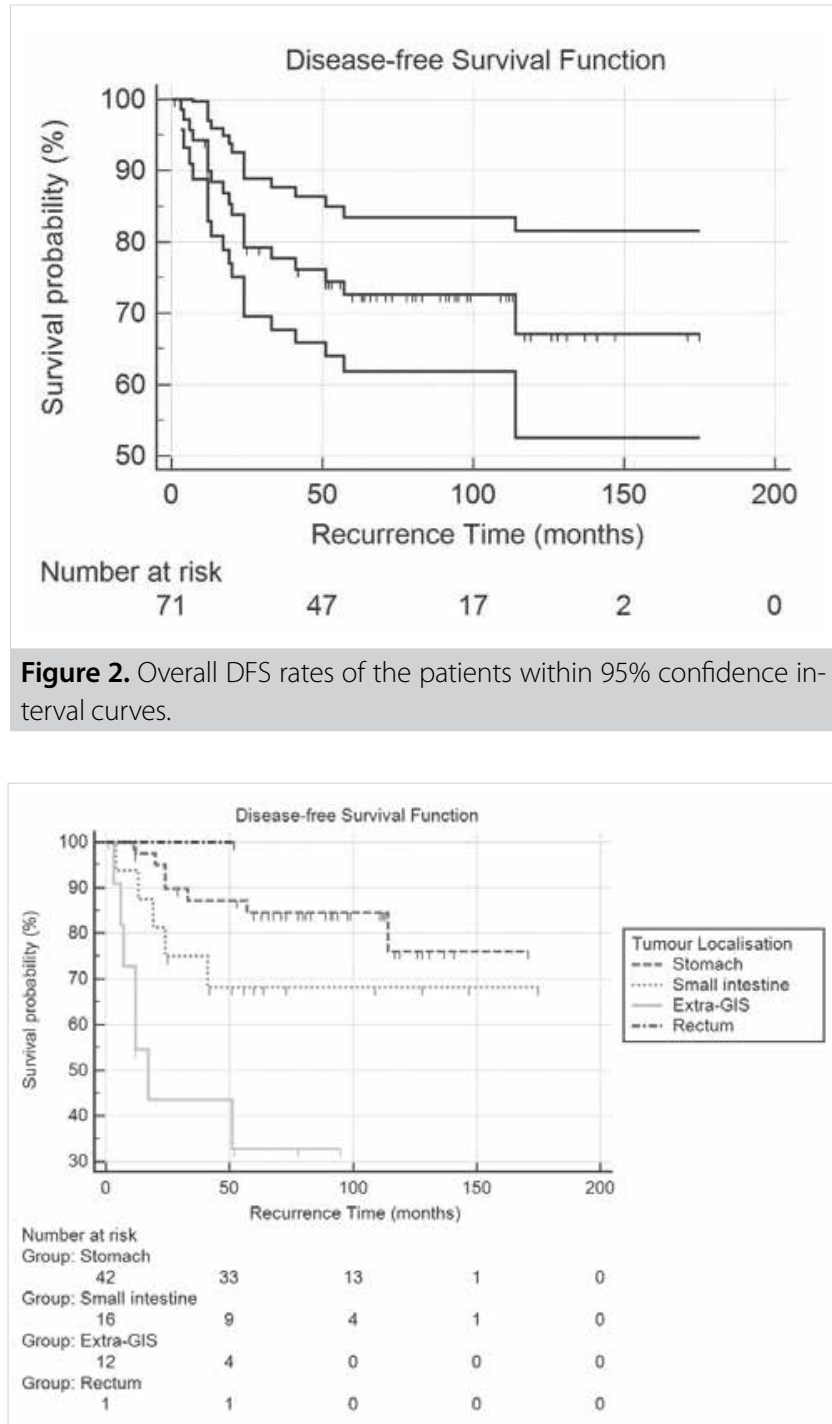

Figure 3. DFS rates of the patients according to tumor localization. 


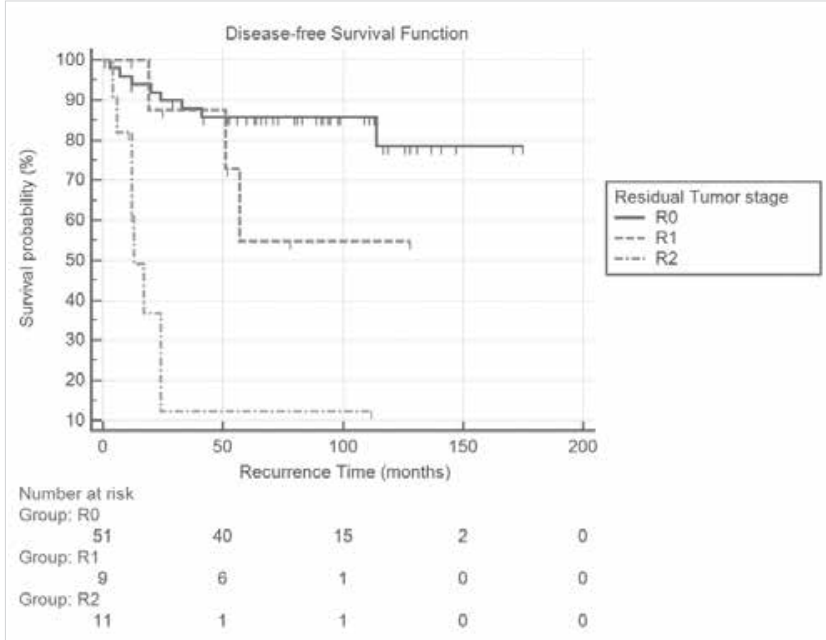

Figure 4. DFS rates of the patients according to residual tumor stage.

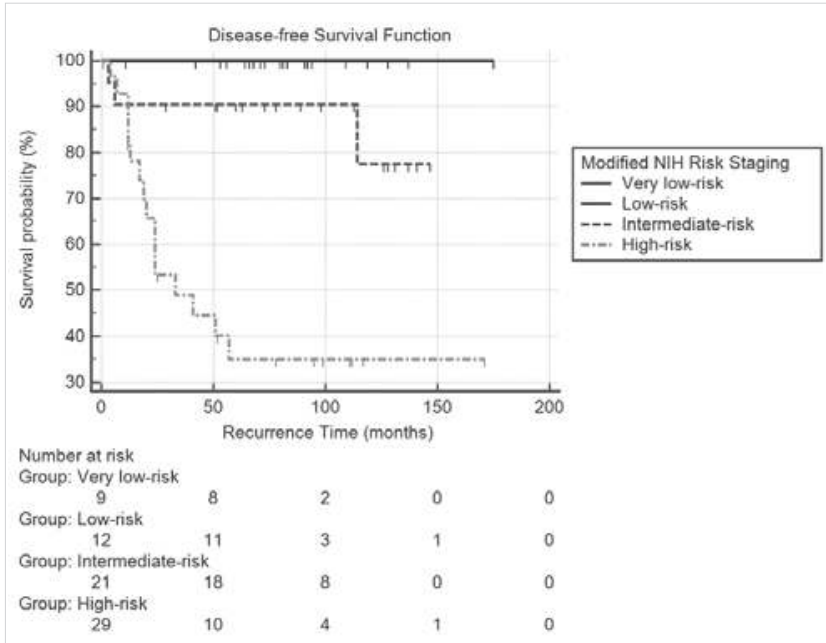

Figure 5. DFS rates of the patients according to the modified NIH risk staging scheme.

restricted perforation during the operation. Tumor rupture was observed in 11 (15.9\%) patients, with a mean tumor diameter of $10.91 \pm 3.51 \mathrm{~cm}$ (range: $4.5-15 \mathrm{~cm}$ ). Five of the 8 relapsed patients in the $\mathrm{R} 0$ resection group, 1 of the 3 relapsed patients in the R1 resection group and 5 of the 8 relapsed patients in the R2 resection group died due to progressive disease. Predicted DFS rates of the patients in the R0 group [141 months, 95\% Cl (123-160), Log Rank $=28.54, p<0.001]$ were significantly higher compared to the R1 [60 months, 95\% Cl (43-76), Log Rank=28.54, p<0.001] and R2 groups [20 months 95\% Cl (9-32), Log Rank=28.54, p<0.001]. DFS rates of residual tumor classification were significantly different between the groups $(p<0.001)$ (Figure 4). Restricted tumor perforation and tumor rupture were not associated with DFS rates with insignificant $p$ values, 0.380 and 0.208 , respectively.

Twelve (63.2\%) patients in tumor diameter $>10 \mathrm{~cm}$ group relapsed, and 5 of them died. One patient in the tumor diameter
$<5 \mathrm{~cm}$ group and six patients in tumor diameter $5-10 \mathrm{~cm}$ group relapsed, and five of them died. DFS rates of tumor diameter $>10$ $\mathrm{cm}$ group were significantly lower than the other group of patients [63 months, 95\% Cl (31-95), Log Rank= 17.75, p< 0.001]. Additionally, tumor local invasiveness and tumor positive resection margin significantly decreased DFS rates $(p<0.002$ and $p<0.032)$. However, tumor invasion depth was not found to be associated with decreased DFS rates $(p=0.488)$.

Tumor necrosis, moderate and severe cellular atypia, mitosis count 5-10, and $>10$ per 50/HPF and desmine were found to be significantly associated with decreased DFS rates $(p<0.005)$. Tumor histology, mucosal ulceration, central hemorrhage, and immune histochemical markers including CD117, CD34, actin, S-100, Ki-67, NSE were not different between the groups with insignificant $p$ values ( $p>0.05$ ).

Modified $\mathrm{NIH}$ risk stratification groups of very low-risk and low-risk groups did not present any recurrence or death during follow-up. Three of the 21 patients in the intermediate-risk group, 16 of the 29 patients in the high-risk group relapsed, and three patients in the intermediate-risk group and eight patients in the high-risk group died. First, $3^{\text {rd }}$, and $5^{\text {th }}$-year DFS rates for very-low and lowrisk groups were $100 \%$. First and $3^{\text {rd }}$-year DFS rates for the intermediate-risk group were $90.2 \%$, and $5^{\text {th }}$-year survival rates were $82 \%$. First, $3^{\text {rd }}$, and $5^{\text {th }}$-year Disease-free survival rates for high-risk groups were $82.1 \%, 48.9 \%$, and $34 \%$, respectively. DFS rates were lower in intermediate- and high-risk groups due to 10 (14.8\%) of the 12 deaths in the high-risk group and 2 (2.81\%) of the four deaths in the intermediate-risk group regarding disease progression or recurrence. DFS rates were found to be significantly different between the risk groups ( $<<0.001)$, and higher risk increases recurrence and decreases recurrence-related survival (Figure 5).

Metastasis was observed in 22 (30.9\%) patients during the follow-up period. In this study, 13 (18.3\%) patients were metastatic on admission, with liver metastasis in 6 (8.44\%) patients, peritoneal metastasis in 5 (7\%) patients, lung metastasis in 1 (1.4\%) patient and gastric metastasis in 1 (1.4\%) patient. Besides, 11 (15.4\%) patients developed new metastatic foci during follow-up; 3 (4.2\%) in the liver, 5 (7\%) in the peritoneum, $2(2.8 \%)$ in the small intestine and $1(1.4 \%)$ in the subcutaneous tissue. Presence of metastasis on admission and tumor progression during follow-up screening were significantly associated with decreased DFS rates $(p<0.001)$.

Adjuvant tyrosine kinase inhibitor (TKI) therapy was not administered to the very-low and low-risk group, and disease-related death and recurrence were not present in these group of patients. Eighteen patients in intermediate- and high-risk group were administered with TKI, and 11 (61.2\%) of the patients died during follow-up. Only 8 (24.2\%) of the 33 patients in the intermediate- and the high-risk group without TKI adjuvant therapy presented with recurrence-related death. Disease-free survival rates of patients receiving adjuvant therapy were significantly 
different between these groups $(p<0.001)$. Besides that, disease-free survival rates of the high-risk group without adjuvant TKI therapy and low-risk group with and/or without adjuvant TKI therapy groups were found to be similar. However, DFS rates of the high-risk group with adjuvant TKI therapy were significantly decreased compared to the other groups ( $p<0.001)$. The main factor of this difference was all of the remaining patients were metastatic on admission or progressive during follow-up, except four patients in the high-risk group with adjuvant TKI therapy. DFS rates were significantly different between groups in univariate analysis $(p<0.001)$

The univariate analysis of the factors affecting DFS was summarized in Table 1

Tumor location, tumor diameter, mitosis count, Modified-NIH score, residual tumor stage, per-operative local invasive disease, positive margins, metastasis on admission and follow-up, tumor necrosis, desmine and adjuvant therapy were found to be significant values in the univariate analysis with $p$ value $<0.20$ and were entered to the multivariate analysis with Cox-regression models (Table 2).

Multivariate analysis presented recurrence rate and recurrence-related death risks in patients with GIST. Recurrence risk of the small intestine and extra-GIS tumors were found to be 10 and 84 times higher than the gastric tumors. Small intestine and extra-GIS localization of the tumors were determined as unfavorable factors for DFS. Mitosis count $<5$ per 50/HPF presented eight times more adverse effect over recurrence risk and increased DFS rates. $R 2$ resection also increases the risk of recurrence and adversely affects DFS up to 38 times. Although locally invasive disease was found to be significant in exploration, its contribution to the development of recurrence was low. It was observed that the risk of recurrence increased fourfold in the high-risk group receiving adjuvant therapy compared to the untreated group.

\section{DISCUSSION}

GISTs are rare mesenchymal tumors that are thought to originate from interstitial Cajal cells. GISTs are slightly more common in the male sex with a median age of 60 years (7-9). Gender is not defined as a prognostic factor for survival and recurrence $(10,11)$. Although the majority of the patients in our study were male, a statistically significant relationship was not presented between gender and recurrence. Approximately $70 \%$ of the patients are asymptomatic on diagnosis. Presenting complaints are abdominal pain, abdominal mass, weakness, and fatigue due to occult bleeding. As the clinical course of the disease complicates, several symptoms are interlinked to each other. Abdominal mass and pain were found to be strongly associated with the survival in this study. The presence of these symptoms should be noticed in patients with a presumptive diagnosis of GIST in terms of assessing the severity of the disease.
GISTs are classified into four groups in the Modified NIH risk staging system as very low-, low-, intermediate- and high-risk groups according to localization, tumor diameter, and mitotic index (12). Risk staging systems provide invaluable information in predicting the prognosis and clinical course of the disease. In addition, many studies have shown that very low, low, and intermediate-risk groups have similar clinical results and present favorable prognosis. Therefore, in the light of the staging systems, adjuvant therapy with tyrosine kinase inhibitors are considered for patients only in the high-risk group as a conclusion. Risk staging systems have also presented a significant difference between the risk groups in terms of recurrence, overall survival, and DFS (Figure 6). In the literature, the effects of anatomical localization to the overall survival remains controversial. Gastric tumors have been described with better clinical outcomes compared to distal tumors $(13,14)$. Although lower incidence rates of colonic and rectal GISTs complicate the identification of associated risk factors, recent studies have demonstrated that colonic and rectal tumors present worse prognosis rather than the gastric tumors (6,15-17). Prognosis of small intestine localized GISTs is not markedly different from colonic and rectal GISTs at ten years (6). Primary GISTs of the omentum, mesentery, and pancreas are rarely described in the literature; however, they are highly presented in this study and provide an advantage in comparing overall survival and DFS rates. Tumor localization was not found to be statistically associated with overall survival, but tumor recurrence was different between the groups. DFS rates of extra-GIS tumors were significantly lower than the gastric and small intestine tumors. Multivariate analysis demonstrated the recurrence and recurrence-related death risks of the small intestine and extra-GIS tumors up to 10-fold and 84fold, respectively, compared to the gastric tumors. These results were consistent with those reported in the literature.

Effective treatment of GISTs is still surgery. Clinical manifestations of stromal tumors may vary due to the complicated clinical course of the disease in terms of recurrence risk and metastasis even when the tumor is completely resected with the pseudo-capsule $(13,18)$. In locally invasive disease, en-bloc resection of the tumor with the surrounding organ or complete removal of the tumor with negative margins mainstay the curative surgery for GISTs. In our study, operation was cautiously performed with extensive resection of the tumor with an intact surgical margin, including metastatic foci and local invasive sites. Predicted DFS rates of the patients in the R0 group were significantly higher compared to the R1 and R2 groups. However, residual tumor stage was not statistically associated with the survival but presented as a significant prognostic parameter for disease recurrence. In the literature, there are conflicting reviews over the effects of positive microscopic surgical margins regarding survival $(19,20)$. In the recent Modified NIH (Fletcher) risk staging system, tumor rupture during the operation may alter clinical outcomes and may increase disease stage regardless of any tumor size, localization and mitotic count 
Table 1. Univariate analysis of the factors affecting disease-free survival

\begin{tabular}{|c|c|c|c|c|c|c|c|}
\hline Variables & $N$ & $1^{\text {st }}$ year $^{\mathrm{a}}$ & $3^{\text {rd }}$ year $^{a}$ & $5^{\text {th }}$ year $^{\mathrm{a}}$ & $\begin{array}{l}\text { Estimated } \\
\text { survival }^{\mathrm{b}}\end{array}$ & Log-Rank & $p$ \\
\hline $\begin{array}{l}\text { Localization } \\
\text { Stomach } \\
\text { Small intestine } \\
\text { Extra-GIS } \\
\text { Rectum }\end{array}$ & $\begin{array}{c}42 \\
16 \\
12 \\
1\end{array}$ & $\begin{array}{c}88.8 \\
93.8 \\
70.7 \\
-\end{array}$ & $\begin{array}{c}85.5 \\
70.8 \\
37.9 \\
-\end{array}$ & $\begin{array}{c}76 \\
60.7 \\
15.6 \\
-\end{array}$ & $\begin{array}{c}138(116-160) \\
88(61-116) \\
33(10-56)\end{array}$ & 20.57 & 0.001 \\
\hline $\begin{array}{l}\text { Residual tumor stage } \\
\text { R0 } \\
\text { R1 } \\
\text { R2 }\end{array}$ & $\begin{array}{c}51 \\
9 \\
11\end{array}$ & $\begin{array}{c}91.5 \\
- \\
81.8\end{array}$ & $\begin{array}{l}86.3 \\
85.7 \\
12.3 \\
\end{array}$ & $\begin{array}{c}79.9 \\
42.9 \\
-\end{array}$ & $\begin{array}{c}141(123-160) \\
60(43-76) \\
20(9-32)\end{array}$ & 28.54 & 0.001 \\
\hline $\begin{array}{l}\text { Tumor diameter } \\
\qquad 5 \mathrm{~cm} \\
\quad 5-10 \mathrm{~cm} \\
>10 \mathrm{~cm}\end{array}$ & $\begin{array}{l}23 \\
29 \\
19\end{array}$ & $\begin{array}{l}100 \\
85.9 \\
83.3\end{array}$ & $\begin{array}{c}90 \\
78.2 \\
44.9\end{array}$ & $\begin{array}{c}- \\
- \\
25.6\end{array}$ & $\begin{array}{c}118(102-134) \\
89(74-104) \\
63(31-95)\end{array}$ & 17.75 & 0.001 \\
\hline $\begin{array}{l}\text { Mitosis count } \\
<5 / \text { per } 50 \mathrm{HPFC} \\
\text { 5-10/per } 50 \mathrm{HPF} \\
>10 / \text { per } 50 \mathrm{HPF}\end{array}$ & $\begin{array}{c}46 \\
9 \\
15\end{array}$ & $\begin{array}{c}93 \\
- \\
80\end{array}$ & $\begin{array}{c}84.2 \\
- \\
40\end{array}$ & $\begin{array}{c}- \\
22.9 \\
-\end{array}$ & $\begin{array}{c}146(128-164) \\
63(39-86) \\
41(24-57)\end{array}$ & 10.27 & 0.006 \\
\hline $\begin{array}{l}\text { Modified NIH groups } \\
\text { Very low-risk } \\
\text { Low-risk } \\
\text { Intermediate-risk } \\
\text { High-risk }\end{array}$ & $\begin{array}{c}9 \\
12 \\
21 \\
29\end{array}$ & $\begin{array}{c}- \\
- \\
90.2 \\
82.1\end{array}$ & $\begin{array}{c}- \\
- \\
90.2 \\
48.9\end{array}$ & $\begin{array}{l}- \\
- \\
82 \\
34\end{array}$ & $\begin{array}{c}119(99-138) \\
- \\
- \\
- \\
-\end{array}$ & 18.680 & 0.001 \\
\hline $\begin{array}{l}\text { Necrosis } \\
\text { Present } \\
\text { Absent }\end{array}$ & $\begin{array}{l}21 \\
48 \\
\end{array}$ & $\begin{array}{l}84.2 \\
93.8 \\
\end{array}$ & $\begin{array}{l}48.1 \\
88.8 \\
\end{array}$ & $\begin{array}{c}28.9 \\
85\end{array}$ & $\begin{array}{c}47(30-64) \\
148(131-165)\end{array}$ & 15.30 & 0.001 \\
\hline $\begin{array}{l}\text { Margin positive } \\
\text { Present } \\
\text { Absent }\end{array}$ & $\begin{array}{l}20 \\
51\end{array}$ & $\begin{array}{l}84.1 \\
91.8\end{array}$ & $\begin{array}{l}43.1 \\
86.9\end{array}$ & $\begin{array}{l}34.5 \\
75.5\end{array}$ & $\begin{array}{c}42(27-57) \\
136(115-156)\end{array}$ & 9.89 & 0.002 \\
\hline $\begin{array}{l}\text { Local invasiveness } \\
\text { Present } \\
\text { Absent }\end{array}$ & $\begin{array}{l}18 \\
49\end{array}$ & $\begin{array}{l}88.5 \\
91.4\end{array}$ & $\begin{array}{l}52.5 \\
86.4\end{array}$ & $\begin{array}{l}43.8 \\
74.1\end{array}$ & $\begin{array}{c}55(36-74) \\
134(112-155)\end{array}$ & 4.62 & 0.032 \\
\hline $\begin{array}{l}\text { Desmin } \\
\text { Present } \\
\text { Absent }\end{array}$ & $\begin{array}{l}14 \\
47\end{array}$ & $\begin{array}{l}85.7 \\
97.8\end{array}$ & $\begin{array}{l}61.4 \\
87.4\end{array}$ & $\begin{array}{c}- \\
76\end{array}$ & $\begin{array}{c}35(22-47) \\
137(117-158)\end{array}$ & 8.63 & 0.003 \\
\hline $\begin{array}{l}\text { Metastasis on admission } \\
\text { Present } \\
\text { Absent }\end{array}$ & $\begin{array}{l}13 \\
58\end{array}$ & $\begin{array}{l}69.2 \\
94.5\end{array}$ & $\begin{array}{l}49.5 \\
81.4\end{array}$ & $\begin{array}{c}33 \\
72.2\end{array}$ & $\begin{array}{c}41(23-59) \\
131(111-150)\end{array}$ & 8.45 & 0.004 \\
\hline $\begin{array}{l}\text { Metastasis on follow-up } \\
\text { Var } \\
\text { Yok }\end{array}$ & $\begin{array}{l}22 \\
49\end{array}$ & $\begin{array}{l}77.3 \\
95.5\end{array}$ & $\begin{array}{l}51.5 \\
87.4\end{array}$ & $\begin{array}{l}27.5 \\
80.7\end{array}$ & $\begin{array}{c}41(28-54) \\
143(124-161)\end{array}$ & 14.19 & 0.001 \\
\hline $\begin{array}{l}\text { Progression on CT } \\
\text { First } \\
\text { Second } \\
\text { Third }\end{array}$ & $\begin{array}{l}18 \\
17 \\
16\end{array}$ & $\begin{array}{c}72.2 \\
70.6 \\
75\end{array}$ & $\begin{array}{l}52.5 \\
28.2 \\
34.1\end{array}$ & $\begin{array}{c}19.7 \\
9.4 \\
12.8\end{array}$ & $\begin{array}{c}37(25-48) \\
- \\
-\end{array}$ & $\begin{array}{l}9.20 \\
34.34 \\
24.24\end{array}$ & $\begin{array}{l}0.002 \\
0.001 \\
0.001\end{array}$ \\
\hline $\begin{array}{l}\text { Adjuvant therapy } \\
\text { Present } \\
\text { Absent }\end{array}$ & $\begin{array}{l}18 \\
53\end{array}$ & $\begin{array}{l}83.3 \\
92.1\end{array}$ & $\begin{array}{l}44.9 \\
86.7\end{array}$ & $\begin{array}{l}28 \\
80\end{array}$ & $\begin{array}{c}53(29-79) \\
141(123-160)\end{array}$ & 13.46 & 0.001 \\
\hline $\begin{array}{l}\text { Low-risk group } \\
\text { Adjuvant therapy (+) } \\
\text { Adjuvant therapy (-) }\end{array}$ & $\begin{array}{c}3 \\
39\end{array}$ & $\begin{array}{l}66.7 \\
97.4\end{array}$ & - & $\begin{array}{c}- \\
92\end{array}$ & $\begin{array}{l}86(22-151) \\
93(85-100)\end{array}$ & 2.33 & 0.127 \\
\hline $\begin{array}{l}\text { High-risk group } \\
\text { Adjuvant therapy (+) } \\
\text { Adjuvant therapy (-) }\end{array}$ & $\begin{array}{l}15 \\
14\end{array}$ & $\begin{array}{l}86.7 \\
76.9\end{array}$ & $\begin{array}{l}39.4 \\
59.8\end{array}$ & $\begin{array}{l}19.7 \\
51.3\end{array}$ & $\begin{array}{c}36(23-50) \\
97(55-140)\end{array}$ & 11.12 & 0.001 \\
\hline
\end{tabular}


Table 2. Cox regression analysis of the factors affecting disease-free survival

\begin{tabular}{|c|c|c|c|c|c|c|c|c|}
\hline \multirow[b]{2}{*}{ Variables } & \multirow[b]{2}{*}{$\beta$} & \multirow{2}{*}{$\begin{array}{l}\text { Standard } \\
\text { deviation }\end{array}$} & \multirow[b]{2}{*}{ Wald } & \multirow[b]{2}{*}{ SD } & \multirow[b]{2}{*}{$\mathrm{p}$} & \multirow[b]{2}{*}{$\operatorname{Exp}(\beta p)$} & \multicolumn{2}{|c|}{$95 \% \mathrm{Cl}^{\mathrm{a}} \operatorname{Exp}(\beta p)$} \\
\hline & & & & & & & Lowest & Highest \\
\hline $\begin{array}{l}\text { Localization, } \\
\text { Small intestine }\end{array}$ & 2.285 & 0.776 & 8.670 & 1 & 0.003 & 9.824 & 2.147 & 44.958 \\
\hline $\begin{array}{l}\text { Localization, } \\
\text { Extra-GISc }\end{array}$ & 4.428 & 1.098 & 16.256 & 1 & 0.001 & 83.738 & 9.731 & 720.590 \\
\hline $\begin{array}{l}\text { Mitosis } \\
<5 / \text { per } 50 \mathrm{HPF}\end{array}$ & -2.023 & 0.804 & 6.331 & 1 & 0.012 & 0.132 & 0.027 & 0.640 \\
\hline R2 resection ${ }^{d}$ & 3.634 & 1.293 & 7.897 & 1 & 0.005 & 37.859 & 3.003 & 477.377 \\
\hline Local Invasiveness & -3.453 & 1.350 & 6.542 & 1 & 0.011 & 0.032 & 0.002 & 0.446 \\
\hline $\mathrm{TKI}^{\mathrm{b}}$ therapy & 1.364 & 0.655 & 4.332 & 1 & 0.037 & 3.912 & 1.083 & 14.130 \\
\hline
\end{tabular}

(6). Tumor rupture has a critical role in abdominal dissemination and disease recurrence. In this study, there was no significant relationship between tumor rupture and tumor recurrence risk, and DFS. However, incomplete surgery and invasion of surrounding tissue increased the risk of recurrence up to 38-fold and adversely affected the DFS rates in multivariate analysis. Approximately 50\% of the GISTS are metastatic on admission, and frequently metastasize to the liver and peritoneum, but extra-abdominal metastasis is very rare $(21,22)$. In the literature, peritoneal and liver metastasis at the time of diagnosis indicates poor prognosis, and cases with incidentally detected serosa implants are presented with better outcomes (18). Metastasis on admission and during follow-up was statistically significant in the univariate analysis, but lack of significant data in the multivariate analysis manifested that metastatic disease was not an independent prognostic parameter on DFS. Complete removal of the tumor with the pseudo-capsule and intact surgical margins were presented as the most important prognostic factors over recurrence and DFS.

As a component of risk stratification systems, tumor morphology, immune-histochemistry, and mitotic index are also described as critical prognostic parameters $(13,18)$. Miettinen et al. have demonstrated that spindle cell histology of GIST presents poor prognosis (21). Furthermore, lower cellularity has been described as a useful prognostic factor, while severe nuclear atypia has been mostly seen in aggressive tumors $(23,24)$. In our study, cell type, cellularity, and nuclear pleomorphism had no statistically significant effect on recurrence. Tumor diameter was statistically correlated with both survival and recurrence risk in the univariate analysis. The estimated DFS was found to be lower in patients with tumor size greater than $10 \mathrm{~cm}$. However, multivariate analysis did not present any significant difference between tumor diameter and both overall survival and DFS. Patients with a high mitotic index, > 10 per 50/HPF, are considered in the high-risk group regardless of tumor size (25). In the literature, recurrence risk ratio in patients with mitosis count $>5$ per $/ 50$ HPF is increased up to 14.6-fold. In our study, high mitotic index presented a significant relationship between survival and recurrence. The increase in mitosis negatively affects DFS. The estimated mean DFS at 95\% $\mathrm{Cl}$ is 41 (24-57) months in patients with mitosis count $>10$ per 50/HPF and is lower than the other groups. In multivariate analysis, mitosis count $<5$ per 50/HPF decreased the recurrence risk by 8 -fold. The mitotic index has been reported in the literature as the most important independent prognostic factor affecting recurrence and survival following surgery $(6,15,21)$, and this data is also consistent with this study. Morphological characteristics of the tumor, including necrosis and hemorrhage in the tumor center, ulceration of the mucosa are common and relatively critical prognostic factors $(18,26)$. In our study, tumor necrosis was observed as a risk factor for recurrence in the univariate analysis, but no statistically significant correlation was found for ulceration and bleeding. The presence of necrosis had a significant effect on DFS, but not as an independent factor alone.

Although surgery plays a pivotal role in GIST treatment, long-term follow-up outcomes have presented unsatisfactory results as the sole treatment option. The introduction of tyrosine kinase inhibitors (TKI) has demonstrated more favored clinical outcomes with the propagation of ongoing phase III randomized clinical trials $(27,28)$. In the literature, 5 -year survival following curative surgery with a diagnosis of primary GIST was possible in approximately $54 \%$ of the patients, whereas the risk of recurrence increases up to $40 \%$ in the second year following the operation $(14,29)$. Although studies have attempted to reveal prognostic factors affecting recurrence, especially the recurrence itself, decreases survival and increases mortality. In this study, recurrence affected survival with unfavorable outcomes compared to the other prognostic markers and increased the recurrence-related death risk up to 30 times in a year.

\section{CONCLUSION}

This study evaluated the prognostic parameters of surgical management of GISTs to estimate the risk factors for treatment strat- 
egy and prediction of tumor recurrence before and after surgery. Tumor mitotic index was found to be the most effective and invaluable histologic parameter in the prediction of DFS estimates. Extra-GIS and small intestine tumors were both presented with higher recurrence, incomplete surgery and decreased the DFS rates according to the gastric localized tumors. Besides that, regardless of tumor characteristics, R0 resection was described as another important criteria in terms of increasing survival rates and decreasing the risk of recurrence in advanced-stage disease. In patients with a stromal tumor, the main objectives should be prioritized to maintain curative treatment, reduce the risks of recurrence and the burden of metastatic disease and provide a satisfactory quality of life. As mentioned in this study, complete removal of the tumor with intact margins through effective surgical intervention is considered as the most essential factor in the management of GISTs. Although recent studies have propagated tyrosine kinase inhibitors as a potent agent in adjuvant therapy following the surgery to prevent recurrence and improve survival with favorable outcomes in patients with advanced metastatic disease, this study showed limited or no benefit. Therefore, prospective randomized clinical trials involving more patients with comprehensive and trustworthy statistical data are required to determine the most appropriate medical and surgical therapy in terms of multidisciplinary approach.

\section{ACKNOWLEDGEMENT}

We thank our colleagues from the General Surgery Department who performed the operations. We also thank the anonymous reviewers for their useful suggestions.

Ethics Committee Approval: Approval was obtained from the Ankara Numune Training and Research Hospital Scientific Research Evaluation Commission for the study (Date: 29.01.2014, Decision no: 2014-748).

Informed Consent: Informed consent form was obtained from all patients.

Peer-review: Externally peer-reviewed.

Author Contributions: Concept - K.S., G.D.Ö.; Design - K.S.; Supervision G.D.Ö., N.A.K., A.Z.A.; Materials - G.D.Ö., N.A.K., A.Z.A.; Data Collection and/or Processing - K.S.; Analysis and Interpretation - K.S., G.D.Ö.; Literature Review - K.S., G.D.Ö.; Writing Manuscript - K.S.; Critical Reviews - G.D.Ö

Conflict of Interest: The authors have no conflicts of interest.

Financial Disclosure: Financial support was provided by departmental sources.

\section{REFERENCES}

1. Grignol VP, Termuhlen PM. Gastrointestinal stromal tumor surgery and adjuvant therapy. Surg Clin North Am 2011; 91 (5): 1079-87. [CrossRef]

2. Tran T, Davila JA, El-Serag HB. The epidemiology of malignant gastrointestinal stromal tumors: an analysis of 1,458 cases from 1992 to 2000. Am J Gastroenterol 2005; 100 (1): 162-8. [CrossRef]
3. Graadt van Roggen JF, van Velthuysen ML, Hogendoorn PC. The histopathological differential diagnosis of gastrointestinal stromal tumours. J Clin Pathol 2001; 54 (2): 96-102. [CrossRef]

4. Gold JS, Dematteo RP. Combined surgical and molecular therapy: the gastrointestinal stromal tumor model. Ann Surg 2006; 244 (2): 176-84. [CrossRef]

5. Nilsson B, Bumming P, Meis-Kindblom JM, Oden A, Dortok A, Gustavsson $B$, et al. Gastrointestinal stromal tumors: the incidence, prevalence, clinical course, and prognostication in the preimatinib mesylate era--a population-based study in western Sweden. Cancer 2005; 103 (4): 821-9. [CrossRef]

6. Joensuu H, Vehtari A, Riihimaki J, Nishida T, Steigen SE, Brabec P, et al. Risk of recurrence of gastrointestinal stromal tumour after surgery: an analysis of pooled population-based cohorts. Lancet Oncol 2012; 13 (3): 265-74. [CrossRef]

7. Miettinen M, Lasota J. Gastrointestinal stromal tumors--definition, clinical, histological, immunohistochemical, and molecular genetic features and differential diagnosis. Virchows Arch 2001; 438 (1): 1-12. [CrossRef]

8. Miettinen M, Lasota J. Gastrointestinal stromal tumors: review on morphology, molecular pathology, prognosis, and differential diagnosis. Arch Pathol Lab Med 2006; 130 (10): 1466-78. [CrossRef]

9. Koay MH, Goh YW, lacopetta B, Grieu F, Segal A, Sterrett GF, et al. Gastrointestinal stromal tumours (GISTS): a clinicopathological and molecular study of 66 cases. Pathol 2005; 37 (1): 22-31. [CrossRef]

10. Miettinen M, Lasota J. Gastrointestinal stromal tumors. Gastroenterol Clin North Am 2013; 42 (2): 399-415. [CrossRef]

11. Hatipoglu E, Demiryas S. Gastrointestinal stromal tumors: 16 years experience within a university hospital. Rev Esp Enferm Dig 2018; 110 (6): 358-64. [CrossRef]

12. Fletcher CD, Berman JJ, Corless C, Gorstein F, Lasota J, Longley BJ, et al. Diagnosis of gastrointestinal stromal tumors: a consensus approach. Hum Pathol 2002; 33 (5): 459-65. [CrossRef]

13. Emory TS, Sobin LH, Lukes L, Lee DH, O'Leary TJ. Prognosis of gastrointestinal smooth-muscle (stromal) tumors: dependence on anatomic site. Am J Surg Pathol 1999; 23 (1): 82-7. [CrossRef]

14. DeMatteo RP, Lewis JJ, Leung D, Mudan SS, Woodruff JM, Brennan MF. Two hundred gastrointestinal stromal tumors: recurrence patterns and prognostic factors for survival. Ann Surg 2000; 231 (1): 51-8. [CrossRef]

15. Dematteo RP, Gold JS, Saran L, Gonen M, Liau KH, Maki RG, et al. Tumor mitotic rate, size, and location independently predict recurrence after resection of primary gastrointestinal stromal tumor (GIST). Cancer 2008; 112 (3): 608-15. [CrossRef]

16. Miettinen M, Lasota J. Gastrointestinal stromal tumors: pathology and prognosis at different sites. Semin Diagn Pathol 2006; 23 (2): 70-83. [CrossRef]

17. Miettinen M, Furlong M, Sarlomo-Rikala M, Burke A, Sobin LH, Lasota J. Gastrointestinal stromal tumors, intramural leiomyomas, and leiomyosarcomas in the rectum and anus: a clinicopathologic, immunohistochemical, and molecular genetic study of 144 cases. Am J Surg Pathol 2001; 25 (9): 1121-33. [CrossRef]

18. Miettinen M, El-Rifai W, Sobin LHL, Lasota J. Evaluation of malignancy and prognosis of gastrointestinal stromal tumors: a review. Hum Pathol 2002; 33 (5): 478-83. [CrossRef]

19. Catena F, Di Battista M, Ansaloni L, Pantaleo M, Fusaroli P, Di Scioscio $V$, et al. Microscopic margins of resection influence primary gastrointestinal stromal tumor survival. Onkologie 2012; 35 (11): 645-8. [CrossRef] 
20. McCarter MD, Antonescu CR, Ballman KV, Maki RG, Pisters PW, Demetri GD, et al. Microscopically positive margins for primary gastrointestinal stromal tumors: analysis of risk factors and tumor recurrence. J Am Coll Surg 2012; 215 (1): 53-9. [CrossRef]

21. Miettinen M, Sobin LH, Lasota J. Gastrointestinal stromal tumors of the stomach: a clinicopathologic, immunohistochemical, and molecular genetic study of 1765 cases with long-term follow-up. Am J Surg Pathol 2005; 29 (1): 52-68. [CrossRef]

22. Connolly EM, Gaffney E, Reynolds JV. Gastrointestinal stromal tumours. Br J Surg 2003; 90 (10): 1178-86. [CrossRef]

23. Sturgeon C, Chejfec G, Espat NJ. Gastrointestinal stromal tumors: a spectrum of disease. Surg Oncol 2003; 12 (1): 21-6. [CrossRef]

24. Dei Tos AP. The reappraisal of gastrointestinal stromal tumors: from Stout to the KIT revolution. Virchows Arch 2003; 442 (5): 421-8. [CrossRef]

25. Joensuu H. Risk stratification of patients diagnosed with gastrointestinal stromal tumor. Hum Pathol 2008; 39 (10): 1411-9. [CrossRef]
26. Goldblum JR, Appelman HD. Stromal tumors of the duodenum. A histologic and immunohistochemical study of 20 cases. Am J Surg Pathol 1995; 19 (1): 71-80. [CrossRef]

27. Learn PA, Sicklick JK, DeMatteo RP. Randomized clinical trials in gastrointestinal stromal tumors. Surg Oncol Clin North Am 2010; 19 (1): 101-13. [CrossRef]

28. Scaife CL, Hunt KK, Patel SR, Benjamin RS, Burgess MA, Chen LL, et al. Is there a role for surgery in patients with "unresectable" CKIT+ gastrointestinal stromal tumors treated with imatinib mesylate? Am J Surg 2003; 186 (6): 665-9. [CrossRef]

29. Molinas Mandel N, Selcukbiricik F, Kanitez M, Yalcin S, Tural D, Erdamar S, et al. Clinical and pathological characteristics and their effect on survival in elderly patients with gastrointestinal stromal tumors. JBUON 2016; 21 (2): 360-5. [CrossRef]

\title{
ORIJINAL ÇALIŞMA-ÖZET
}

Turk J Surg 2020; 36 (2): 209-217

\section{Cerrahi tedavi uygulanan gastrointestinal stromal tümörlü hastalarda nüks ve hastalıksız sağkalıma etki eden faktörlerin retrospektif analizi}

\author{
Kazım Şenol ${ }^{1,2}$, Gül Dağlar Özdemir ${ }^{3}$, Arif Zeki Akat ${ }^{3}$, Nuri Aydın Kama ${ }^{4}$ \\ ${ }^{1}$ Uludağ Üniversitesi Tıp Fakültesi, Genel Cerrahi Anabilim Dalı, Bursa, Türkiye \\ ${ }^{2}$ Ankara Numune Eğitim ve Araştırma Hastanesi, Genel Cerrahi Bölümü, Ankara, Türkiye \\ ${ }^{3}$ Sağlık Bilimleri Üniversitesi Tıp Fakültesi, Genel Cerrahi Anabilim Dalı, Ankara, Türkiye \\ ${ }^{4}$ Abant Izzet Baysal Üniversitesi Tıp Fakültesi, Genel Cerrahi Anabilim Dalı, Bolu, Türkiye
}

\section{ÖZET}

Giriş ve Amaç: Bu çalışmada, hastaların operasyon sonrasında rekürrens riski ve hastalıksız sağkalımına etki eden cerrahi ve cerrahi dışı prognostik faktörlerin ortaya konulması ve tümöral dokunun sağlam cerrahi sınırla birlikte tamamen çıkarılması ve adjuvan tedavi kullanımın sonuçlarının araştırılması amaçlanmıştır.

Gereç ve Yöntem: 2005-2013 yılları arasında gastrointestinal stromal tümör tanısı ile opere edilmiş 71 hastanın klinik ve demografik özellikleri, tümör lokalizasyonu, tümörün morfolojik ve histopatolojik özellikleri, sağkalım ve nüks zamanını içeren verileri geriye dönük olarak kaydedildi.

Bulgular: Yetmiş bir olgunun, erkek/kadın oranı, 1,71 ve yaş ortalaması 60,27 $\pm 14,65$ yıldır. Hastaların tümör lokalizasyonları, 42 (\%59,2)'sinde mide, $16(\% 22,5)$ 'sında ince bağırsak, $12(\% 16,9)$ 'sinde ekstra gastrointestinal sistem, $1(\% 1,4)$ 'inde rektumdadır. Modifiye NIH risk sınıflamasına göre, 9 (\%12,68)'u çok düşük, $12(\% 16,90)$ 'si düşük, 21 (\%29,58)'i orta ve 29 (\%40,85)'u yüksek risk grubunda yer almıştır. Hastaların 13 $(\% 18,3)$ 'ünde başvuru anında metastaz izlenirken, 24 (\%33,8) hastada takipte nüks veya metastaz gelişmiştir. R0 rezeksiyon 51 (\%71,8)'inde, R1 rezeksiyon $9(\% 12,7)$ 'unda, R2 rezeksiyon 11 (\%15,5)'inde sağlanabilmiştir. Ortalama takip süresi 47,12 $\pm 33,52$ ay (aralık: 1-171) olarak izlenmiş olup, nüks izlenen $19(\% 26,8)$ hastanın ortalama nüks zamanı 22,16 $\pm 15,89$ aydır (aralık: 3-57). Takip süresi boyunca $54(\% 76,1)$ hasta sağken, 17 (\%23,9)'si yaşamını yitirmiştir. Tek değişkenli analizde yüksek evre, ince bağırsak, ekstra gastrointesinal sistem yerleşimi, R1-2 rezeksiyon, nekroz, çevre doku invazyonu ve cerrahi sınır pozitifliği, metastatik hastalık ve adjuvan tedavi kullanımı nüks riskini artırırken, çok değişkenli analizde hastalıksız sağkalıma ince bağırsak, ekstra gastrointestinal sistem yerleşimi, R2 rezeksiyon, mitoz sayısı, çevre invazyonu ve adjuvan tedavi hastalıksız sağkalım üzerinde bağımsız prognostik faktörler olarak izlenmiştir. Hastaların bir yıllık, üç yıllık ve beş yıllık hastalısız sağkalım değerleri sırasıyla $\% 89.6, \% 75.4, \% 64.3$ olarak izlenmiştir.

Sonuç: Literatürde tanımlandığı gibi, gastrointestinal stromal tümörlerin küratif tedavisinde en önemli basamak cerrahidir. Çalışmamızda hastalığın ince bağırsak ve ekstra gastrointestinal sistem yerleşimli olması, tümörün çevre dokuya invaze görünümü tümörün lokal kontrolünü zorlaştırmakta ve R2 rezeksiyonla birlikte hastalıksız sağkalım için bağımsız kötü prognostik faktörler olarak izlenmektedir. Adjuvan tedavinin hastalıksız sağkalım üzerinde izlenen olumsuz etkisi yüksek evreli metastatik hastalığa bağlanmakta ve bu yönde daha geniş sayılı ve ileriye dönük çalışmalar yapılması gerekliliğini ortaya koymaktadır.

Anahtar Kelimeler: Gastrointestinal stromal tümörler, cerrahi, prognoz, hastalıksız sağkalım

Doi: $10.5578 /$ turkjsurg.4389 
218 Factors affecting disease-specific survival and recurrence in gastrointestinal stromal tumors 